\title{
IMPLEMENTATION OF ENERGY LAW OF HYBRID POWER STATION FOR SOCIAL WELFARE*
}

\author{
Dyah Ayu Widowati**
}

\author{
Departemen Hukum Agraria, Fakultas Hukum, Universitas Gadjah Mada, Yogyakarta \\ Jalan Sosio Yustisia Nomor 1 Bulaksumur, Sleman, D.I. Yogyakarta 55281
}

\begin{abstract}
This study was aimed to investigate the Implementation of Energy Law of Hybrid Power Station for Social Welfare in Pantai Baru. The problem formulations are the management and utilization of hybrid power station in Pantai Baru and implementation of energy law of hybrid power station for social welfare in the fields of economy and information in Pantai Baru. Based on data analysis it is concluded that the management of hybrid power station in Pantai Baru is performed collaboratively between government and the society. The existence of hybrid power station in pantai baru has positive impacts in economy and information.
\end{abstract}

Keywords: energy law, hybrid power station, social welfare.

\section{Intisari}

Penelitian ini meneliti Pelaksanaan Hukum Energi Pembangkit Listrik Tenaga Hibrid untuk Kesejahteraan Rakyat di Bidang Ekonomi dan Informasi di Pantai Baru. Masalah yang diteliti adalah bentuk pengelolaan dan pemanfaatan pembangkit listrik tenaga hibrid di Pantai Baru dan pelaksanaan hukum energi pembangkit listrik tenaga hibrid untuk kesejahteraan rakyat di bidang ekonomi dan informasi di Pantai Baru. Berdasarkan analisis data dapat disimpulkan bahwa pengelolaan pembangkit listrik tenaga hibrid yang ada di pantai baru dilakukan secara kolaboratif, antara pemerintah dengan masyarakat. Kehadiran pembangkit listrik tenaga hibrid yang ada di pantai baru telah memberikan dampak positif di bidang ekonomi dan informasi.

Kata kunci: hukum energi, pembangkit listrik tenaga hibrid, kesejahteraan masyarakat.

\section{Pokok Muatan}

A. Background 333

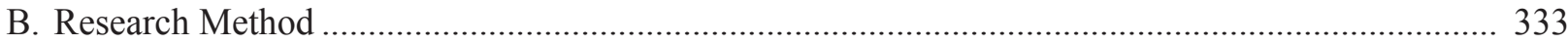

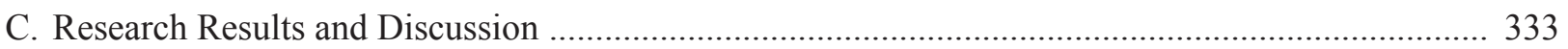

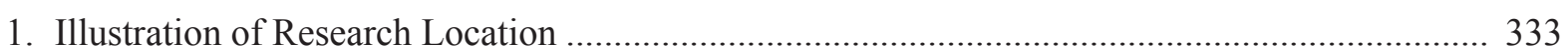

2. Management and Utilization of Hybrid Power Station in Pantai Baru, Srandakan

Sub-District, Bantul Regency, Special Region of Yogyakarta.

3. Implementation of Energy Law of Hybrid Power Station for Social Welfare in the Fields of Economy and Information in Pantai Baru, Srandakan Sub-District, Bantul Regency,

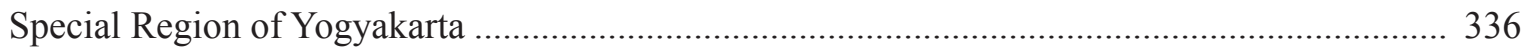

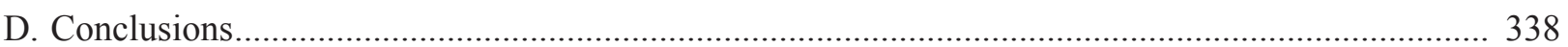

" Individual research, 2014.

** Correspondence address: d.ayu.ugm@gmail.com 


\section{A. Background}

Along with the increase of human population, many negative impacts occur due to increasing needs. However those needs, such as needs for soil, are limited because the amount of soil on earth doesn't increase, while people who need it steadily increase. This eventually creates various crises, such as food crisis, energy crisis, etc. Indonesia is one of the countries which experience such crippling condition, where there is an explosion of population, so that the needs for oil increases, but this isn't followed by the increase of national oil production. To meet national oil needs, Indonesia still depends on imports.

Therefore, energy diversification efforts are required to create a good energy balance. Energy diversification can be done by giving opportunities to many kinds of alternative energies which have been developed or new energy types. There are several alternatives which can be developed, e.g. natural gas, geothermal, biomass, water, wind, wave, solar, geothermal, and others which are open for development. Nowadays the government has realized the importance of energy management, as seen in the release of Presidential Decree No. 5 of 2006 on National Energy Policy, which is a policy to realize energy diversification in 2025. This Presidential Decree is implementing regulation of Law No. 30 of 2007 on Energy.

One of the concrete implementations of Presidential Decree No. 5 of 2006 on National Energy Policy is making Pantai Baru in the territory of Bantul Regency, Yogyakarta as the area of a pilot project to utilize energy resources in an area. Pantai Baru is made into a pilot for constructing hybrid power station because it has stable wind quality and adequate sunlight every year. This project is made based on cooperation agreement between Ministry of Research and Technology, National Aviation and Space Agency, Gadjah Mada University and Bantul Regency Government to be implemented in 2010-2013 period. Based on the background above, the formulations of the problems in this study are: Firstly, what are the management and utilization of hybrid power station in Pantai Baru, Srandakan Sub-District, Bantul Regency, Special Region of Yogyakarta? Secondly, what is the implementation of energy law of hybrid power station for social welfare in the fields of economy and information in Pantai Baru, Srandakan Sub-District, Bantul Regency, Special Region of Yogyakarta?

\section{B. Research Method}

This study is a field and literature study because the data obtained to discuss the problems came from the results of literature study and field study. Literature study was aimed to get references related to definitions and classifications of natural resources, the concept of renewable energy types of renewable energies and organization of energy resources. Field study was expected to reveal the implementation of energy law of hybrid power station for social welfare in the fields of economy and information in Pantai Baru, Srandakan SubDistrict, Bantul Regency, Special Region of Yogyakarta. Data analysis used in this study is qualitative analysis, which is where data collected from the study is connected to theories from normative study to be presented, so that a descriptive qualitative description is produced. The purpose of this analysis method is to get comprehensive answer which adheres to regulations in effect on the problems discussed.

\section{Research Results and Discussion \\ 1. Illustration of Research Location}

Srandakan Sub-District is in Southwest of the capital of Bantul regency. Srandakan Sub-District has total area of $1.454,8831$ Ha. Srandakan SubDistrict territory is bordered by:
a) north : Pajangan Sub-District.
b) east Pandak and Sanden Sub- District.
c) south : Indian Ocean.
d) west : Progo River, Galur Sub-Dis- trict, Kulon Progo Regency.

Srandakan Sub-District consists of 2 villages, which are Poncosari Village and Trimurti Village. 
Trimurti Village is the center of furniture industry and tofu industry. While Poncosari Village is the center of tempe industry and tourism. There are many tourist attractions in Poncosari Village, such as cultural tourism e.g. Rasulan Ceremony/Bersih Dusun Poncosari, Poncosari Sea Alms (Sedekah Laut) Ceremony, and there is technology tourism with the existence of hybrid power station in Pantai Baru which is located in the area of Poncosari Village.

\section{Management and Utilization of Hybrid Power Station in Pantai Baru, Srandakan Sub-District, Bantul Regency, Special Region of Yogyakarta}

a. Management of Hybrid Power Station in Pantai Baru, Srandakan Sub-District, Bantul Regency, Special Region of Yogyakarta

Management of natural resources is determined by the human's mentality and view on the natural resources. Conservative view (pessimistic view or Malthusian) on natural resources make human more careful in utilizing natural resources, because they face uncertain future. Another extreme view is exploitative view (Ricardian perspective). In this perspective, natural resources are the engine of growth. Human transform natural resources into manmade capitals which have higher values, making human productivity and welfare higher/better. ${ }^{1}$

Natural resources such as soil, sea, air, oil, forest, etc. are essential natural resources. The development of every region is influenced by the natural resources potential of each region. To optimize the potentials of every region, community empowerment is required. Community empowerment can have a multiplier effect, because community empowerment can increase community's awareness on environment, as well as contributing to increasing social welfare, which can be seen as improvement of economic and social conditions.

The economic improvement of a region doesn't only depend of the community or the government separately. The government and the community as well as private parties and academics must work together to carry out development, for example by developing knowledge and technology to be applied for economic improvement. These knowledge and technology will produce various innovations called regional innovation system. In the Joint Regulation of Minister of Research and Technology No. 3 of 2012 and Minister of Home Affairs No. 36 of 2012 on Reinforcement of Regional Innovation System, it is mentioned that regional innovation system is the entire process in a system to grow innovations which are done between government institutions, local government, research and development institutions, education institutions, innovation supporting institutions, business world, and local community. ${ }^{2}$

Yogyakarta has great nautical potential, because it has a large coastal area, including Bantul area which becomes the location of this research. Is one of the regencies in Southern Special region of Yogyakarta. Development in the energy sector in Bantul Regency is performed through development and utilization of renewable energy potentials (EBT). This follows Government policy of energy diversification. The implementation of energy policy is performed using the following policy measures: ${ }^{3}$

Ernan Rustiadi, et al., 2011, Perencanaan dan Pengembangan Wilayah, Crestpent Press dan Yayasan Pustaka Obor Indonesia, Jakarta, pp. 211-212

Kementerian Ristek dan Teknologi, 2013, Sistem Inovasi Daerah Menggerakkan Ekonomi (Pengalaman Membangun PLTH Angin dan Surya di Bantul), Kementerian Riset dan Teknologi, Jakarta, p. 37.

Abdul Kadir, 2010, Energi (Sumber daya, Inovasi, Tenaga Listrik dan Potensi Ekonomi), UI Press, Jakarta, p. 542. 
(1) The first measure is intensification effort, which is increase of energy sources surveys and explorations. Explorations of new reserves of petroleum and natural gas, coal, geothermal, water power, radioactive mineral, and biomass will be increased.

(2) The second measure is diversification, which is strategic effort to reduce dependency on petroleum to met national energy needs and replace it with other forms of energy.

(3) The third measure is conservation, which is various efforts to use more efficient energy.

(4) The fourth measure is indexation principle. Scientific methods are used to determine which types of energy are most suitable to be used by each activity sector.

Effort to increase the use of renewable energy and expand the scope of electricity to all villages in Bantul regency is done by developing alternative energy by utilizing existing and environmentally sound natural resources (solar, wind, and biogas powers). ${ }^{4}$ Pantai Baru is a region often used to hold rocket races initiated by Gadjah Mada University. Since it's often used for rocket races, slowly it's discovered that Pantai Baru area has wind quality which can be made into renewable energy by using wind power to produce electricity.

The frequent uses Pantai Baru as the location of rocket races bring many researchers to discover another potential of Pantai Baru. This resulted in the creation of a program to establish hybrid power station because Pantai Baru has stable wind power every year and because it is a coastal area, so that sun ray in this area should be enough to become the power source to produce electricity. ${ }^{5}$ Hybrid power is a technology which combines to moving power sources. This is why the power station in pantai baru is called hybrid power station (PLTH), because this PLTH utilizes renewable energy the primary source and combines it with diesel generator as additional energy source (secondary).

In the PLTH in pantai baru the renewable energy used comes from solar energy and wind energy combined using diesel generator set to make a more effective and efficient power station to supply electricity needs of the community. ${ }^{6}$ The appointment of Pantai Baru as the pilot project to build hybrid power station is based on cooperation agreement between four institutions, which are Ministry of Research and Technology, National Aviation and Space Agency, Gadjah Mada University and Bantul Regency Government which will be implemented in 2010-2013 period. Aside from the four institutions above, the construction of PLTH also involves Ministry of Marine Affairs and Fisheries as well as village officers.

The agreement made by Ministry of Research and Technology, Gadjah Mada University, National Aviation and Space Agency and Bantul Regency Government is the implementation of Law No. 30 of 2007 on Energy, because the law mentions that the government and local governments are obligated to develop renewable resources and it funding is regulated by article 30 clause (2) of Law No. 30 of 2007 on Energy from the State Budget, Regional Budget, and private funds.

The construction of PLTH has regular layout of the area, which divides the area

Local Regulation of Bantul Regency No. 1 of 011 on Medium Term Development Plan of Bantul Regency 2011-2015. Interview with Bapak Ir. Ag . Waryanto, Head Field of Marine and Fisheries Department of Marine and Fisheries Bantul.

Interview with Bapak Edy Purwanto, Head Sub-Field of Statistical Data and Reporting of Regional Planning and Development Agency Bantul. 
into two zones, which are core zone and supporting zone. The core zone of the PLTH is the coastal area, because the location of PLTH is in the coastal area. Administratively Pantai Baru region is a part of Poncosari Village, or specifically Ngentak Hamlet. While the supporting zone is administratively a part of Trimurti Village, both villages are in the territory of Srandakan Sub-District.

b. Utilization of Hybrid Power Station in Pantai Baru, Srandakan SubDistrict, Bantul Regency, Special Region of Yogyakarta

Hybrid Power Station in Pantai Baru is currently only utilized by the community living near Pantai Baru, this is because the power capacity produced is not enough to supply larger community and its scope is also not very far. The existence of Hybrid Power Station which can only be used by people living near the coast can not be questioned by people living far from the coast, because Law No. 30 of 2007 on Energy in article 20 clause (3) mentions that the area producing energy source get the priority of energy distribution from the local energy source.

Current utilizations of electricity generated by PLTH are for food stalls along Pantai Baru, to make ice, for farming, animal husbandry and fishery, as well as for household needs. With PLTH, agriculture, animal husbandry and fishery along Pantai Baru can be relied on for the livelihoods of the community, because with PLTH people can easily get water by using water pumps. Before PLTH, agriculture and animal husbandry did not give maximum yields due to lack of water, which had to be collected manually, without water pumps. People who can use electricity generated by the PLTH are determined by activity group. After determining those who can use it, people who use the electricity produced by the PLTH should give compensation by paying fifty thousand rupiah per ampere meter. The minimum cost is 300 rupiah per meter, this is far cheaper compared with the cost of electricity from State Electricity Company (PLN) which is around 450 rupiah per meter. ${ }^{7}$

PLTH in Pantai Baru is a pilot project, so there are many problems in its implementation, such as lack of human resources to maintain the machines used to produce electricity, and the equipments used must be bought in Jakarta, this is because the spare parts needed are not commonly used, only available in Jakarta. Aside from that the technology of the equipments used in PLTH should be improved continuously, for example the lightning rod because the existing lightning rod has been hit by lightning so that it's broken and broke the wind turbine, disturbing electricity distribution. Therefore, a more advanced lightning rod is required to avoid the same condition to happen again.

3. Implementation of Energy Law of Hybrid Power Station for Social welfare in the Fields of Economy and Information in Pantai Baru, Srandakan Sub-District, Bantul Regency, Special Region of Yogyakarta

a. Implementation of Energy Law of Hybrid Power Station for Social welfare in the Field of Economy

Management of natural and energy resources has social welfare as the final objective for, e.g., source of foreign exchange, fulfilling human needs, regional/community development and equalization. ${ }^{8}$ Social welfare is one of the principles and purposes of Law No. 30 of 2007 of Energy, as stated in Article 2 that energy is managed based

Interview with Bapak Adam Santosa, S.Ag., Public Relations of Hybrid Power Station.

Sukanto Reksohadiprodjo, 2007, Ekonomi Sumber Daya Alam dan Energi, BPFE, Yogyakarta, p. 14. 
on the principles of expediency, rationality, just efficiency, increase of added value, sustainability, social welfare, preservation of environmental functions, national defence, and integration by prioritizing national capacity.

It is further described in article 3 letter (f) that the increase of the access of poor people and/or people who live in remote area to energy to realize social welfare and prosperity equally by: (1) providing assistance to increase energy availability for poor people; and (2) building energy infrastructures to undeveloped areas to reduce the disparity between regions. The existence of PLTH in Pantai Baru has created a tremendous change in the community in Pantai Baru, especially by the emergence of culinary stalls along Pantai Baru. These culinary stalls utilize Sultanaat ground which is separated into several parts to build stalls. Before PLTH the area of Pantai Baru was only used for agriculture and fishery, culinary stalls now found in Pantai Baru didn't exist because there was no electricity, so Pantai Baru wasn't known by the society.

After the construction PLTH, the government cooperates with activity group, especially activity group of Ngentak Hamlet, to make activities to follow up the construction of PLTH in Pantai Baru. The concrete measure taken was by announcing drawing places of business on the coast of Pantai Baru for people of Ngentak Hamlet who were interested. Registrations to get places of business on the coast of Pantai Baru have been done in two terms. In the first term in 2010 there were 100. In 2013 the openings were only open for $2^{\text {nd }}$ and $3^{\text {rd }}$ classes, $1^{\text {st }}$ class was no longer open. Places of business which would be draws were divided into three classes divided by size and entrance fee, so people have places of business options which fit their individual economic capacity. Aside from the three classes above, there is vendor class near the terminal in Pantai Baru area.

Utilization of the coastal area of Pantai Baru is prioritized for the people of Ngentak Hamlet, because the requirements for registration for the raffle are identification card (KTP) and family card (C1) which show that they are actual residents and live in Ngentak Hamlet. Sharecroppers who have used the coast of Pantai Baru before the construction of PLTH each gets the priority for 1 plot of place of business

Table I. Class Division for Places of Business

\begin{tabular}{cccc}
\hline \multirow{2}{*}{ Class } & \multirow{2}{*}{ Size } & \multicolumn{2}{c}{ Entrance Fee } \\
\cline { 3 - 4 } & & $\mathbf{2 0 1 0}$ & $\mathbf{2 0 1 3}$ \\
\hline I & $14 \times 20$ meter & Rp. 500.000 & - \\
II & $6 \times 9$ & Rp. 250.000 & Rp. 400.000 \\
III & $3 \times 6$ & Rp. 100.000 & Rp. 200.000 \\
\hline
\end{tabular}

Source: Data of Ngentak Hamlet Activity Group 2013.

Everyone who has registered for the raffle in I, II, III classes must use the spot given, if they get a place but do not use it for business and build it according to the criteria of each class, then the place of business will be taken back by the activity group organizing distribution of plots and given to other interested people. To supervise the usage of the plots so that it matches the target, each class is give time limits. The time limits are: $1^{\text {st }}$ Class has 6 months, $2^{\text {nd }}$ Class has 3 months, $3^{\text {rd }}$ Class had 2 months. In that time frame, the plot must be built upon and used. Time tolerance for using the plots is 1 month at maximum after the period of each class ends.

Before the construction of PLTH, the coastal area of Pantai Baru was used for agriculture, but the plants only depended on rainfall and wells, so the yields were not maximal. After the construction of PLTH, agricultural and freshwater fisheries sectors can develop because with PLTH, water needs 
can be met. The government also aids the construction of ice factory to develop fishery sector. The ice produced by this ice factory is used to supply the fishermen, so that the freshness of catches can be preserved, but the ice is also used to supply food stalls.

The government constructed PLTH not only to meet the electricity needs of local community, but also to develop the tourism sector of Pantai Baru. Therefore, the government repaired streets infrastructures and helped the promotions to introduce Pantai Baru. The existence of PLTH made Pantai Baru unique beach tourism compared with other beaches around it, because the tourists coming to Pantai Baru do not only enjoy the view, but also technological tourism. ${ }^{9}$

However, the economic improvement is only experienced by the community around the beach, because Trimurti Village which becomes the supporting area of the PLTH has not experienced any economic improvement from the existence of PLTH. This is because Trimurti Village doesn't get electricity supply from PLTH due to distance constraints, so it uses electricity from PLN which is more expensive than electricity price of PLTH. Furthermore, in Trimurti Village there is only PLTH workshop, which does not contribute to economic improvement of the people of Trimurti Village. ${ }^{10}$

\section{b. Implementation of Energy Law of Hybrid Power Station for Social} Welfare in the Field of Information

Although not directly, the existence of PLTH does not only improve the economy of the community around the beach, but also improve the fulfilment of information needs. This is because with the construction of PLTH many college students did field work $(\mathrm{KKN})$ in the area. The presence of college students had positive impacts in the field of information, because they teach the community to use technology such as laptop, internet and even teach them to create websites, to promote Pantai Baru.

Improvement of fulfilment of society's information needs is limited through interaction with people from outside the region who come for vacation. Improvement of fulfilment of information needs form other media such as internet has not existed, because even though there is PLTH there is no construction of other infrastructures, such as tower provider, so that telecommunication network in the area of Pantai Baru has not improved.

\section{Conclusion}

Based on the results and discussion above, several conclusions can be drawn: First, Management of hybrid power station in Pantai Baru up to 2013 is still done collaboratively between all parties who made cooperation agreement to construct hybrid power station, and people who are the representatives of activity group (pokgiat). Utilization of hybrid power station is still limited for community living near the coastal area. This is because the electricity produced by PLTH is still limited and the range of electricity distribution isn't very far. In the utilization of PLTH in Pantai Baru there are many problems, such as shortage of human resources to maintain the PLTH, and shortage of equipment needed. Second, the existence of hybrid power station in pantai baru has given positive impacts, i.e. economic improvement, especially for the community around the beach, because the community living in the supporting area of PLTH, Trimurti village, has not experienced economic improvement from the existence of PLTH. Economic improvement experienced by the community living near the beach mostly comes from culinary stalls they run along the beach. With 
the existence of PLTH, the government supports in repairing streets infrastructures and promotions. Aside from economic improvement, the community living around the beach also experiences other benefits from the PLTH, which is improvement of fulfilment of information needs. This is because with PLTH, a lot of people come to Pantai Baru, not only tourists but also institutions which have community empowerment programs, for example college students who had field work and give training to the community in using technology to access information.

There are two suggestions from this study, which are: Firstly, The management of PLTH in Pantai Baru should be followed by coordination between the government and community, so that the transfer of knowledge in maintaining PLTH can be done smoothly, so that the community can independently run the PLTH. Transfer of knowledge shouldn't be limited to maintenance and operation of equipment, but also making spare parts. Beside that the implementation of electricity system project should be reinforced by regulations at level of local regulations so that it can larger scope and has strong legal force. Secondly, In constructing PLTH the government should follow it up by encouraging other parties, such as telecommunication companies, to build cell phone towers around PLTH, to improve telecommunication network, so that communication is smoother and the community can access internet easily. Beside that the implementation of electricity system project should be reinforced by regulations at level of local regulations so that it can larger scope and has strong legal force.

\section{BIBLIOGRAPHY}

\section{A. Books}

Kadir, Abdul, 2010, Energi (Sumber daya, Inovasi, Tenaga Listrik dan Potensi Ekonomi), UI Press, Jakarta.

Kementerian Ristek dan Teknologi, 2013, Sistem Inovasi Daerah Menggerakkan Ekonomi (Pengalaman Membangun PLTH Angin dan Surya di Bantul), Ministry of Research and Technology, Jakarta.

Reksohadiprodjo, Sukanto, 2007, Ekonomi Sumber Daya Alam dan Energi, BPFE, Yogyakarta.
Rustiadi, Ernan, et al., 2011, Perencanaan dan Pengembangan Wilayah, Crestpent Press and Yayasan Pustaka Obor Indonesia, Jakarta.

\section{B. Regulations}

Law No. 30 of 2007 on Energy (State Gazette of the Republic of Indonesia of 2007 No. 96, Additional State Gazette of the Republic of Indonesia No. 4746).

Local Regulation No. 1 of 2011 on Medium Term Development Plan of Bantul Regency 20112015. 